\title{
„Według własnego uznania, dla dobra publicznego, poza nakazami prawa..." Ślady Lockeańskiej koncepcji prerogatywy w kulturze politycznej USA
}

\begin{abstract}
The article refers to the class of situations in which abandoning the principle of legalism occurred in connection with the threat to the basic interests of a society and a state. The political history of the United States provides numerous examples of this kind of events. During international armed conflicts involving the US, civil wars or revolutions, the political leaders of this modern constitutional state have often decided to breach the law in order to overcome the danger threatening „the life of the nation”. One of the explanations for this state of affairs was the fact that the constitution of 1787 , as distinguished from many other contemporary national constitutions, did not contain detailed solutions for the times of crisis. The activity of American presidents in the area of national security was grounded on expanding interpretations of their competences defined in the Basic Law. One of the theoretical grounds for president's emergency power doctrine was the theory of prerogative elaborated by John Locke in the late 17th century. The article seeks to provide answer to the following paradox. Why did Locke, despite his involvement in developing the idea of the rule of law, also accept exer-
\end{abstract}

1 Karol Dobrzeniecki, Katedra Teorii Prawa i Państwa, Wydział Prawa i Administracji, Uniwersytet Mikołaja Kopernika w Toruniu, Polska, karol.dobrzeniecki@umk.pl. 
cising extra-legal prerogative powers in cases of emergency? The English philosopher defined the prerogative as ,the power to act according to discretion, for the public good, without the prescription of the law, and sometimes even against it". The idea of extra-legal powers has become a recurring motif in the history of the United States' liberal political culture. Proponents of this vision were convicted that uncertainty, contingency and an unforeseen cases are an inherent features of social and political life, which in many cases elude legal regulation. Recently, the renaissance of Locke's theory of prerogative has taken place in connection with the war on terrorism, in form of an extra-legal measures doctrine.

\section{Keywords:}

prerogative, John Locke, emergency powers, presidential inherent powers

\section{PARADOKS JOHNA LOCKE'A}

Kanwę dla poniższych rozważań stanowi wątek z twórczości Johna Locke’a, w którym ten klasyk nowoczesnego państwa i jeden z ojców doktryny liberalnej zawarł następujący pogląd: „ustawodawcy, stanowiąc prawa, nie mogą przewidzieć i zaplanować tego wszystkiego, co może być korzystne dla społeczności”. Oznacza to, że: „wiele spraw, które dla prawa nie mają znaczenia, aby się nimi zajmowało, musi koniecznie być pozostawionych decyzji tego, w czyich rękach znajduje się władza wykonawcza, by rozwiązywał je tak, jak tego wymagać będą korzyści ludu i dobro publiczne” (Locke, 1992, s. 278). Jako środek, który miał posłużyć do realizacji tego celu, wskazał prerogatywę. Zdefiniował ją jako: „władzę działania według własnego uznania, dla dobra publicznego, poza nakazami prawa, a czasem wbrew nim” (Locke, 1992, s. 279).

Pogląd Locke’a może wydać się oryginalny i wręcz zaskakujący z co najmniej kilku powodów. Należy pamiętać, że wygłosił go wielki ideowy antagonista absolutyzmu monarszego, a uczynił to u progu powstania w Anglii monarchii parlamentarnej - formy ustrojowej, której konstytutywnym założeniem było ograniczenie arbitralności władzy królewskiej. Po drugie, wygłosił go ten sam Locke, który opowiadał się za ideą rządów prawa i podziału władz, której istotą jest, że wykonywanie kompetencji publicznych następuje na podstawie ogólnych upoważnień prawnych. Swoje stanowisko na ten temat wyraził w drugim traktacie o rządzie w następujących słowach: „Rząd, posiadając pełną władzę dla dobra społeczeństwa, nie może sprawować jej arbitralnie ani według swego upodobania, lecz poprzez 
ustanowione i ogłoszone prawa, tak aby lud mógł znać zarówno swe obowiązki, jak i był chroniony i bezpieczny w granicach swoich praw. Na rządzących zaś prawa te powinny nałożyć stosowne ograniczenia, by nie wystawić ich na próbę wykorzystania władzy złożonej w ich rękach w celu i w sposób ludowi nieznany i przezeń nieuznany” (Locke, 1992, s. 262).

Aby jeszcze lepiej zobrazować dysonans poznawczy czytelnika Dwóch traktatów o rzq̨dzie związany z takim, a nie innym ujęciem prerogatywy w dziele Locke’a należy syntetycznie nawiązać do historii i genezy instytucji prerogatywy, sięgającej czasów średniowiecza. Wraz z postępującą po podboju normandzkim centralizacją państwa zakres władzy królewskiej w Anglii osiągnął znaczne rozmiary. W szczytowym okresie objął między innymi prawo do żądania od poddanych służby wojskowej, nakładania podatków i stanowienia prawa. W późniejszych latach katalog tych uprawnień systematycznie się kurczył, a mianem prerogatyw, na gruncie angielskiej konstytucji, określano pozostałość właśnie tych pierwotnych przywilejów monarszych, które wciąż mogły być wykonywane w sposób arbitralny. Wiek XVII upłynął pod znakiem ciągłych konfliktów między władcą i parlamentem, których przedmiotem była między innymi kwestia królewskich prerogatyw. Po chwalebnej rewolucji nowi monarchowie, w osobach Wilhelma Orańskiego i jego żony Marii Stuart, zaakceptowali ograniczenie władzy królewskiej (Marshall, 2012, s. 33 i n.), czego widomym znakiem było przyjęcie w 1689 r. Deklaracji Praw (Gregory, 2013, s. 11-43). Mimo to, zakres prerogatyw wciąż nie był jednoznacznie określony. Sądy, w ramach rozstrzygania indywidualnych spraw, uznawały poszczególne królewskie uprawnienia, traktując je jako związane z osobą władcy i z niej niejako emanujące (Carrol, 2009, s. 249). Na początku XIX wieku William Blackstone scharakteryzował prerogatywę jako: „szczególny prymat króla ponad wszystkimi ludźmi i poza zwykłym porządkiem common law z racji jego królewskiej godności” (Blackstone, 1807, s. 239). Wskutek postępującej demokratyzacji brytyjskiego ustroju, użycie prerogatyw stawało się domeną Korony Angielskiej działającej w formie pochodzącego z wyborów rządu, a nie udziałem osobistym konkretnego monarchy (Carrol, 2009, s. 249-252). Albert Venn Dicey stwierdził, że: „Każdy akt, który egzekutywa może podjąć bez upoważnienia Parlamentu jest dokonywany na podstawie prerogatywy” (Dicey, 1915, s. 282-283). Jedynie niewielka część atrybutów suwerenności monarchy angielskiego przetrwała do czasów współczesnych. Podobnie rzecz się miała w innych państwach europejskich. Wraz z rozwojem koncepcji rządów prawa zakres prerogatyw głowy państwa ulegał istotnemu ograniczeniu.

Paradoks zawarty w poglądzie Locke’a na temat prerogatywy polegał więc na tym, że czołowy protoliberalny myśliciel, uznawany za jednego z ojców nowo- 
czesnego konstytucjonalizmu, opowiedział się za zachowaniem instytucji, która przez stulecia uznawana była za kluczowy instrument absolutyzmu monarszego i związanej z nim arbitralności. On sam bardzo krytycznie podchodził do sposobu korzystania z prerogatyw przez Stuartów. W pierwszym z dwóch Traktatów prowadził polemikę z Robertem Filmerem - zwolennikiem patriarchalnej władzy monarszej i „boskiego prawa królów”, realizowanego w sposób niekrępowany przez absolutystycznego władcę. Absolutyzm monarszy dotknął autora Dwóch traktatów o rzq̨dzie osobiście. W 1683 r. w obawie przez aresztowaniem zmuszony był do wyjazdu do Holandii oraz pobytu przez kilka lat na emigracji (Ogonowski, 1972, s. 37).

\section{PRELOGATYWA JAKO ODPOWIEDŹ NA PROBLEM NIEPRZEWIDYWALNOŚCI ROZWOJU WYPADKÓW}

Warto więc tym bardziej zwrócić uwagę na to, co skłoniło Locke’a do opowiedzenia się za utrzymaniem prerogatywy w nowym ustroju, a wręcz za jej niezbędnością. Główną ideą autora Dwóch traktatów było promowanie fundamentalnych celów konstytucji i służba podstawowym interesom całej społeczności (Dunn, 1969, s. 148 i n.). Za zasadne uznawał pozostawienie władzy wykonawczej spraw podlegających podstawowemu prawu „natury i rządu, które znaczy to samo, co nakaz zachowania, tak dalece, jak to możliwe, wszystkich członków społeczeństwa” (Locke, 1992, s. 278). Dostrzegał problem nieprzewidywalności i przygodności rozwoju wypadków politycznych (contingency), wskazując na niestałość oraz brak pewności, bezpieczeństwa i możliwości kontroli rozwoju wypadków. Twierdził, że: „Rzeczy na tym świecie ulegają stale ciągłym zmianom, tak że nie pozostaje długo w tym samym stanie. Stąd też ludzie, bogactwa, handel, władza zmieniają swe miejsce” (Locke, 1992, s. 275). Locke miał świadomość, że władza ustawodawcza nie dysponuje środkami wystarczającymi do opanowania nieprzewidywalnych zagrożeń. Jej działanie - wyrażające się w stanowieniu prawa - napotyka na liczne ograniczenia. Uznawał, że: „W niektórych formach rządu, władza stanowienia praw nie funkcjonuje nieprzerwanie i z reguły jest sprawowana przez zbyt liczną grupę osób, a zatem zbyt powolna, by uporać się z ich wykonaniem. Jednocześnie zaś jest zupełnie niemożliwe, by przewidzieć i zaplanować przez prawo ustosunkowanie się do wszystkich wydarzeń i potrzeb w życiu publicznym, podobnie jak niemożliwe jest ustanowienie takich praw, które wykonywane w sztywny i rygorystyczny sposób nie będą przynosić szkód, gdy będą stosowane we wszystkich sytuacjach i w stosunku do wszystkich osób. Stąd też uznaniu władzy wykonawczej pozostawia 
się wiele spraw, których prawo nie reguluje” (Locke, 1992, s. 279).

Podstawowymi zasadami prawa naturalnego były dla J. Locke’a obowiązek zachowania społeczeństwa oraz prawo samozachowania (Locke, 1992, s. 269). Nie dostrzegał on sprzeczności między postulowaną przez siebie zasadą ograniczenia władzy przez prawo a dopuszczeniem działań władczych bez podstawy prawnej, jeżeli zajdą określone okoliczności. Właściwie wykonywana prerogatywa pozostaje w zgodzie z porządkiem prawnym i moralnym. Jest nie tyle substytutem prawa, co jego suplementem. Uznanie prerogatyw nie stanowi negacji podstawowych liberalnych wartości ani też nie świadczy o istnieniu sprzeczności w samej teorii. Jest wyrazem pragmatyzmu co do wyboru najlepszych sposobów realizacji tych wartości. Reguły formalne konstytucji służą realizacji wartości materialnych i na nich są oparte. Władza wykonawcza ma szczególne zadanie kontrolne względem innych władz - zadanie realizacji i ochrony celów konstytucji. Stwierdził, że: „cokolwiek bowiem zostanie uczynione, to jeśli potwierdzi się, że dokonano tego sprawiedliwymi i trwałymi środkami, z korzyścią dla społeczeństwa i ludu w ogóle, wtedy w ostatecznym rachunku będzie to zawsze usprawiedliwione” (Locke, 1992, s. 277). Prerogatywa zawsze przynależy do ludu, ponieważ daje się ją zdefiniować wyłącznie w kategoriach jego dobrostanu (Ashcraft, 1987, s. 191).

Locke postrzegał prerogatywę jako władzę działania „poza nakazami prawa, a czasem wbrew nim” (Locke, 1992, s. 279). Wyraźnie oddzielał więc pojęcie prerogatywy i ustawy. Prerogatywa przypisana jest do osoby, jak i do sprawowanego przez nią urzędu. Uzasadnieniem dla jej użycia jest sytuacyjna konieczność, realizuje się przez rządy osobiste, a legitymizuje ją skuteczność podjętych działań. W tym sensie teoria J. Locke’a „przenosi pozostałości przednowożytnego porządku do nowoczesnej konstytucji” (Poole, 2015, s. 51).

Takie rozumienie prerogatywy jest na ogół obce współczesnej nauce prawa konstytucyjnego w kontynentalnych, republikańskich systemach parlamentarno-gabinetowych. Tam bowiem uprawnienia osobiste głowy państwa mają zazwyczaj formalny i techniczno-organizacyjny charakter, szczególnie jeżeli ustawa zasadnicza określa materialnoprawne obowiązki prezydenta, wyznaczając na przykład terminy podejmowania określonych czynności. Prerogatywami nazywa się akty podejmowane bez wymogu kontrasygnaty szefa rządu, które określają zakres swobody prezydenta i jego samodzielności. Zakres ten, w systemie parlamentarno-gabinetowym, zwykle jest stosunkowo wąski, a do tego ściśle wyznaczony przez prawo (Witkowski, 1998, s. 272-286).

Przechodząc do podstawowego przypadku, w którym Locke postuluje użycie prerogatywy, czyli do kwestii opanowania nieprzewidywalnych zagrożeń, należy podkreślić, że zasadniczo rozwój liberalnej kultury politycznej w większości państw 
zachodnich następował w stosunku przeciwnym względem dyrektyw wyłaniających się z jego teorii. W Europie pod koniec XVIII w. narodziła się nowożytna koncepcja stanu nadzwyczajnego. Stanowiło to wyraźne zerwanie z poprzednią epoką. W okresie monarchii absolutnej władza nie była ograniczona prawem stanowionym, co czyniło praktycznie niemożliwym rozróżnienie między stanem normalnym i wykreowanym prawnie stanem nadzwyczajnym (Prokop, 2012, s. 151). Na przestrzeni dziewiętnastego stulecia stopniowo odchodzono od pozalegalnego wykonywania prerogatyw przez głowę państwa w kierunku formalnego przyznawania kompetencji do przeciwdziałania zagrożeniom publicznym (Fatovic, 2009, s. 254). Po pierwszej wojnie światowej upowszechniła się opinia o potrzebie określenia w ustawie zasadniczej normatywnych podstaw wprowadzania stanu nadzwyczajnego oraz jego wpływu na funkcjonowanie państwa i społeczeństwa w okresie trwania określonego typu niebezpieczeństwa (Brzezinski, 2007, s. 18). W późniejszej literaturze sformułowano szereg argumentów przemawiających za regulacją stanów nadzwyczajnych na poziomie ustawy zasadniczej. Każdy z nich wpisywał się nadrzędną rację, tj. zasadę rządów prawa. Jej aspekt formalny wyraża się w stwierdzeniu, że w sytuacji nadzwyczajnej organy państwowe powinny działać na podstawie i w granicach stanowionych przepisów. Jeżeli w pewnych okolicznościach jest to utrudnione, konstytucja ma określać inny tryb funkcjonowania aparatu państwa, tak by nie doprowadzić do paraliżu decyzyjnego, zapewnić pewność prawa i ograniczyć uznaniowość prowadzącą do nadużyć. Zwolennicy liberalnego konstytucjonalizmu na ogół podzielają pogląd, że: „konstytucjonalizacja stanu nadzwyczajnego powoduje skuteczne ograniczenie uprawnień nadzwyczajnych egzekutywy, redukując je do niezbędnego minimum” (Prokop, 2012, s. 151). Aspekt materialny praworządności we współczesnym państwie liberalnym dotyczy przede wszystkim konieczności szczególnej ochrony praw jednostki w sytuacji zagrożenia (Prokop, 2005, s. 10). Wobec tego prawa te uzyskały gwarancje konstytucyjne, podnosi się, że również okoliczności, w których ich ochrona może zostać ograniczona czy zawieszona, powinny być określone na poziomie konstytucyjnym (Gebethner, 1982, s. 17).

\section{KULTURA POLITYCZNA USA W CZASACH KRYZYSU. KONCEPCJE EMERGENCY POWERS}

Analiza praktyki ustrojowej Stanów Zjednoczonych na przestrzeni ostatnich kilku stuleci prowadzi do zaskakujących wniosków. Wskazuje na rozdźwięk pomiędzy literą prawa, w szczególności prawa konstytucyjnego (law in books), a sposobem czynienia z tego prawa użytku przez rządzących (law in action). Istnieje, dostrze- 
galny przez wielu obserwatorów, związek pomiędzy teorią prerogatywy autorstwa J. Locke’a a anglosaską koncepcją stanu nadzwyczajnego (Prokop, 2012, s. 76).

Tezy Locke’a na temat prerogatywy były dobrze znane wielu ojcom założycielom Stanów Zjednoczonych (Levinson, 2006, s. 712). Alexander Hamilton i Thomas Jefferson opowiedzieli się za niezbędnością korzystania przez władzę wykonawczą z prerogatyw w sytuacjach nadzwyczajnych. Uznawali, że rząd, do realizowania celów konstytucji, dysponuje szerszą gamą środków, a nie jedynie prawem. Ważność „pozaprawnych kompetencji” (extra-legal powers) ostatecznie uzależniona jest od czynników materialnych, które nie mogą być w pełni określone przez przepisy. Wobec nadzwyczajnych, nieregularnych i niepowtarzalnych okoliczności i zagrożeń egzekutywa może wprowadzać w życie raczej ducha niż literę prawa. Hamilton twierdził, że działanie takie powinno, co do zasady, mieścić się w granicach konstytucji, a nadzwyczajne okoliczności mogą jedynie prowadzić do przesunięć kompetencji w jej obrębie. Pisał: „Okoliczności zagrażające bezpieczeństwu kraju są nieograniczone i dlatego władzom, którym powierzono troskę o te sprawy, nie można - rozumując roztropnie - narzucić jakichkolwiek ograniczeń konstytucyjnych” (Hamilton, 1999, s. 111). Z kolei Jefferson sytuował uprawnienie do obrony państwa w sferze pozaprawnej i pozakonstytucyjnej, jednak postulował poddanie go kontroli sądowej post-factum. Mimo swego przywiązania do idei ochrony praw podmiotowych i to nawet za cenę politycznej stabilności, uznawał jednak, że: „,utracić kraj przez skrupulatne przestrzeganie pisanego prawa, oznaczałoby utracić prawo jako takie” (Jefferson, 1984, s. 1231).

Do idei prerogatywy szczególnie chętnie powracano w USA w okresach kryzysów politycznych i społecznych. Wobec braku jasnych postanowień regulujących stan nadzwyczajny w ustawie zasadniczej, część doktryny prawa konstytucyjnego rozwijała koncepcję prezydenckich inherent powers, określanych niekiedy, na wzór brytyjski, jako prerogatywy głowy pastwa. W oparciu o nie prezydenci podejmowali bez autoryzacji ustawowej działania tego rodzaju, jak: rekrutacja do armii w wojnie domowej, zbrojne tłumienie strajków, blokada morska czy zawieszanie przywileju Habeas Corpus. Z konstytucyjnej klauzuli artykułu pierwszego, paragrafu ósmego wywodzono uprawniania władz Stanów Zjednoczonych do czynienia wszystkich rzeczy, które są: „konieczne i właściwe” (necessary and proper) do wykonywania przyznanych im uprawnień2.

Wobec nieprzerwanej tradycji konstytucjonalizmu amerykańskiego oraz ciągłości ustroju państwa, większe niż w innych krajach znaczenie zdobyła tam inter-

2 Wyrok Sądu Najwyższego USA z 6 marca 1819 r. w sprawie McCulloch vs Maryland. United States Reports, tom 17, s. 316 i n. 
pretacja historyczna ustawy zasadniczej. Żywa pozostawała konstytucyjna pamięć wydarzeń z okresu wojny secesyjnej. W 1861 r. doszło do konfrontacji pryncypiów ustrojowych młodej demokracji amerykańskiej (w szczególności zasady the rule of law) z koniecznością podjęcia działań służących ochronie istnienia państwa. Prezydent Abraham Lincoln, chcąc stawić czoła narastającej rebelii, dokonał doraźnego, ale również niezgodnego z literalnym brzmieniem ustawy zasadniczej zawieszenia przywileju Habeas Corpus. Jako podstawę swoich działań, co do których legalności sam miał wątpliwości, wskazał „presję obywateli w obliczu zbiorowej konieczności” (Agamben, 2008, s. 35). W liście do senatora Alberta G. Hodgesa napisał: „złożone przeze mnie ślubowanie, w którym zobowiązałem się do ochrony konstytucji wedle mojej najlepszej zdolności, nałożyło na mnie obowiązek zachowania, przy użyciu wszelkich niezbędnych środków, rządu i narodu, dla którego ta konstytucja jest organicznym prawem” (Lincoln, 1989, s. 585).

Doświadczenie wojny secesyjnej stanowiło podstawę do opracowania koncepcji nadzwyczajnych pełnomocnictw (emergency powers) władzy wykonawczej. Michael S. Paulsen zaproponował, aby w przypadku wystąpienia sytuacji nadzwyczajnej odczytywać konstytucję Stanów Zjednoczonych jako konstytucję konieczności (constitution of necessity). Konstytucja zawiera w sobie nadrzędną zasadę konstytucyjnego i narodowego samozachowania. W zgodzie z nią należy dokonywać wykładni poszczególnych postanowień ustawy zasadniczej. W przypadkach nadzwyczajnej konieczności wspomniana zasada przesądza o tym, aby z możliwych interpretacji poszczególnych przepisów Konstytucji wybrać te, które najlepiej służą do realizacji nadrzędnego celu (Paulsen, 2004, s. 1257). Wobec braku szczegółowej regulacji stanu nadzwyczajnego w ustawie zasadniczej Stanów Zjednoczonych, zasadę samozachowania należy odczytać przede wszystkim przy użyciu zasad wykładni systemowej, ze struktury Konstytucji, z przyjętych w niej założeń funkcjonowania stałego konstytucyjnego rządu, a także okoliczności towarzyszących jej powstawaniu. Wielu autorów wyrażało przekonanie, że Ojcowie Założyciele Stanów Zjednoczonych nie mogli pominąć tak ważnej, wręcz fundamentalnej kwestii, jaką jest zagadnienie ocalenia państwa w sytuacji zagrożenia (Paulsen, 2004, s. 1258-1260). Osobisty obowiązek, aby „Konstytucji Stanów Zjednoczonych dochować, strzec i bronić ze wszystkich sił” spoczywa na Prezydencie, który poprzez treść złożonego ślubowania uzyskuje szczególną pozycję w systemie organów władzy ${ }^{3}$. Rola prezydenta określana jest jako

3 Por. treść przysięgi prezydenckiej (presidential oath clause) zawartej w art. 2 Konstytucji Stanów Zjednoczonych Ameryki Północnej z 1787 r., Pudło, A. (tłum.), (2002). Konstytucja Stanów Zjednoczonych Ameryki. Warszawa: Wydawnictwo Sejmowe. 
constitutional stewardship. Oznacza ona m.in. obowiązek odrzucenia wszelkich takich interpretacji ustawy zasadniczej, które uniemożliwiają skuteczne działanie w celu odparcia zagrożenia i mogą prowadzić do konstytucyjnej autodestrukcji. Według M.S. Paulsena logiczną konsekwencją powinności strzeżenia i obrony Konstytucji jest obowiązek ochrony narodu, którego ten akt dotyczy. Takie odczytanie znaczenia roty przysięgi stwarza również możliwość samodzielnego interpretowania ustawy zasadniczej przez prezydenta w sytuacji nadzwyczajnej (Paulsen, 2004, 1258-1262). W skrajnych przypadkach wspomniana powinność może autoryzować naruszenia niektórych postanowień konstytucji w celu ocalenia konstytucji jako całości.

W okresie tzw. wojny z terroryzmem, przypadającej na pierwsze dziesięciolecie XXI wieku, ważnym nowym obszarem zainteresowania amerykańskiej teorii konstytucyjnej stała się kwestia wypracowania republikańskiego modelu prerogatywy, obejmującego kwestię oceny i kwalifikacji różnych typów działań podejmowanych przez władzę wykonawczą w warunkach kryzysu wywołanego przez szczególne zagrożenia. Jednym z nich jest również: „działanie pozakonstytucyjne podejmowane w celu ochrony konstytucyjnej republiki wówczas, gdy działania legalne są niewystarczające do spełnienia tego zadania” (Morteson, 2014, s. 66). Ewentualna akceptacja tego rodzaju pozalegalnych działań, choć w ograniczonym zakresie i tylko na gruncie moralno-politycznym, tworzy szereg wyzwań natury praktycznej. Zmusza także do rozwinięcia teorii bazującej - na przykład - na założeniach doktryn obywatelskiego nieposłuszeństwa zastosowanych odpowiednio do oceny działań władz publicznych. Taka potencjalna teoria powinna obejmować zarówno sferę podmiotową czynu, jak i określać relację tak rozumianej „prerogatywy” do ustaw regulujących kwestie stanów nadzwyczajnych oraz moralnych uzasadnień dla naruszeń prawa (Morteson, 2014, s. 87-95). W literaturze podnosi się także, że z uwagi na legalistyczną kulturę polityczną większości państw rozwiniętych, o wiele częściej niż do prerogatywy, egzekutywa sięga do kontrowersyjnych metod wykładni przepisów po to, by uzasadnić swoje pozaprawne działania (Goldsmith, 2013, s. 214-231).

Interesującym przykładem koncepcji teoretycznej nawiązującej do myśli Johna Locke’a był opracowany krótko po zamachach z 11 września przez Orena Grossa tzw. model środków pozaleganych (extra-legal measures). Stanowił on propozycje odpowiedzi na stan zagrożenia innej niż konwencjonalna w państwie konstytucyjnym, a więc przeprowadzona środkami prawnymi. Generalnym założeniem tego modelu była dopuszczalność odstąpienia od porządku konstytucyjnego w obliczu poważnego niebezpieczeństwa, przy czym do publicznej informacji powinien zostać podany zarówno fakt podjęcia określonych działań tego rodzaju, jak i ich 
pozaprawny charakter. Norma, od której odstąpiono, wciąż obowiązuje, nie została uchylona, zmieniona, ani nawet nie wyłączono jej zastosowania, a więc powinna być wykonywana we wszystkich przewidzianych przez prawo sytuacjach. Odstąpienie od działania zgodnego z dyspozycją normy stanowi więc niewątpliwe naruszenie obowiązującego prawa, podjęte przez funkcjonariusza publicznego w celu zapobieżenia konkretnemu zagrożeniu. Odrębną kwestią pozostaje to, czy sprawca ma zostać za to ukarany. Decyzję w tej kwestii Gross pozostawia społeczeństwu, które ex post winno rozstrzygnąć, czy wymierzyć sankcje, czy też, oceniając retrospektywnie, od tego odstąpić. Do tego czasu funkcjonariusz publiczny działa na własne ryzyko. Celem zaproponowanego rozwiązania jest uniknięcie trwałych przekształceń ustroju pod wpływem sytuacji nadzwyczajnych (Gross, 2003, s. 1096-1133).

Wskazane przykłady potwierdzają trafność cytowanych na wstępie przemyśleń J. Locke’a na temat stosunku liberalizmu do ograniczającego władzę ustawodawstwa w sytuacji zagrożenia. Sanford Levinson stwierdził wręcz, że: „nie sposób zrozumieć amerykańskiego konstytucjonalizmu, bez pozostawienia miejsca dla «prerogatywy» rządu do okazjonalnego zignorowania prawa” (Levinson, 2006, s. 712). Nawet jeżeli akceptacja dla pozaprawnych działań egzekutywy (extra et contra legem) dokonywanych dla dobra publicznego nie jest reguła, to praktyka taka stanowi powtarzający się motyw. Sytuacje nadzwyczajne stanowią więc wyzwanie dla przyjmowanego dość powszechnie poglądu o równoważności liberalizmu i rządów prawa (Dyzenhaus, 2011, s. 69). Współcześni autorzy nawiązujący do J. Locke’a twierdzą, że normy ustanowione dla zwykłych okoliczności są nieadekwatne do sterowania biegiem wypadków, gdy społeczeństwu jako całości grozi bezpośrednie niebezpieczeństwo. Uznają, iż nieprzewidywalność, nagłość zagrożeń tego typu i nieodwracalność wielu ich skutków uzasadnia podejmowanie wszelkich efektywnych i szybkich działań bez prawnego umocowania, a nawet wbrew prawu (Lazar, 2009, s. 159-162). Teoria prerogatywy według Locke’a nie oferuje rozwiązania, które ograniczałoby się wyłącznie do kwestii efektywnościowych. Posiada ona również wymiar normatywny, a odwołująca się do tej konstrukcji egzekutywa jest poddana moralnym ograniczeniom. Jak zauważa Clement Fatovic: „prerogatywa winna brać pod uwagę istniejące moralne i konstytucyjne standardy nawet wówczas, gdy w grę wchodzi naruszenie prawa” (Fatovic, 2009, s. 259). Definicja zaproponowana przed laty przez J. Locke’a zakorzenia prerogatywę w fundamentalnych zasadach konstytucji i w perspektywie prawa naturalnego, skoro jej celem jest promowanie dobra publicznego. Cena jaką płaci się za ochronę materialnych wartości ustrojowych, jest poświęcenie niektórych wartości proceduralnych. Problem ten jest wciąż aktualny. Renesans 
zainteresowania teorią prerogatywy Locke’a na początku XXI wieku dowodzi, że dyskusja nad różnymi postaciami liberalizmu oraz granicami ochrony interesu publicznego kosztem interesów indywidualnych wciąż pozostaje żywa w amerykańskiej kulturze politycznej.

\section{Bibliografia}

Agamben, G. (2008). Stan wyjątkowy. Homo sacer II, 1. Kraków: Ha!art.

Ashcraft, R. (1987). Locke's two treatises of government. London: George Allen \& Unwin. Blackstone, W. (1807). Commentaries on the laws of England. Portland: T.B. Wait \& Co. Brzeziński, M. (2007). Stany nadzwyczajne w polskich konstytucjach. Warszawa: Wydawnictwo Sejmowe.

Carrol, A. (2009). Constitutional and administrative law. Manchester: Longman.

Dicey, A.V. (1915). Introduction to the study of the law of the constitution. London: Macmillan.

Dunn, J. (1969). The political thought of the John Locke. An historical account of the argument of the „Two treaties of government”. Cambridge: Cambridge University Press.

Dyzenhaus, D. (2011). Emergency, liberalism and the state. Perspectives on Politics, 9(1), s. $69-78$.

Fatovic, C. (2009). Outside the law. Emergency and executive power. Baltimore: Johns Hopkins University Press.

Gebethner, S. (1982). Stany szczególnego zagrożenia jako instytucja prawa konstytucyjnego. Państwo i Prawo, 8, s. 5-19.

Gregory, A. (2013). The power of Habeas Corpus in America from the king's prerogative to the war on terror. Cambridge: Cambridge University Press.

Gross, O. (2003). Chaos and rules: should responses to violent crises always be constitutional? Yale Law Journal, 112, s. 1011-1134.

Goldsmith, J. (2013). The irrelevance of prerogative power, and the evils of secret legal interpretation. W: C.B. Fatovic, B.A. Kleinerman (red.), Extra-legal power and legitimacy. Perspectives on prerogative (s. 214-231). Oxford: Oxford University Press.

Gross, O., Ní Aoláin, F. (2006). Law in times of crisis. Emergency powers in theory and practice. Cambridge: Cambridge University Press.

Hamilton, A. (1999). Esej numer 23. W: F. Quinn (red.), Eseje polityczne federalistów. Warszawa: Znak.

Jefferson, T. (1984). Letter to John B. Colvin. A law beyond the constitution (September 20, 1810). W: M.D. Peterson (red.), Thomas Jefferson. Writings. New York: The Library of America.

Lazar, N.C. (2009). States of emergency in liberal democracies. Cambridge: Cambridge University Press.

Levinson, S. (2006). Constitutional norms in a state of permanent emergency. Georgia Law Review, 40, s. 699-751.

Lincoln, A. (1989). Letter from Abraham Lincoln, President of the United States, to Albert 
G. Hodges, U.S. Senator (April 4, 1864). W: D.E. Fehrenbacher (red.), Abraham Lincoln: speeches and writings (s. 585). New York: Library of America. Locke, J. (1992). Dwa traktaty o rządzie. Warszawa: Wydawnictwo Naukowe PWN. Marshall, G. (1985). What are constitutional conventions? Parliamentary Affairs, 38(1), s. 33-39.

Mortenson, J.D. (2014). A theory of republican prerogative. Southern California Law Review, 88, s. 45-95.

Ogonowski, Z. (1972). Locke. Warszawa: Książka i Wiedza.

Paulsen, M.S. (2004). The constitution of necessity. Notre Dame Law Review, 79, s. $1257-1297$.

Poole, T. (2015). Reason of the state. Law, prerogative and empire. Cambridge: Cambridge University Press.

Prokop, K. (2012). Modele stanu nadzwyczajnego. Białystok: Temida 2.

Prokop, K. (2005). Stany nadzwyczajne w Konstytucji Rzeczypospolitej Polskiej. Białystok: Temida 2.

Witkowski, Z. (1998). Prezydent Rzeczypospolitej Polskiej. W: Z. Witkowski (red.), Prawo konstytucyjne. Toruń: Towarzystwo Naukowe Organizacji i Kierownictwa. Stowarzyszenie Wyższej Użyteczności „Dom Organizatora”. 